\title{
Benthic Fluxes on the Oregon Shelf
}

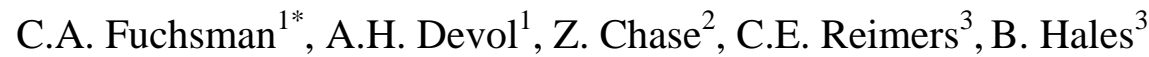

${ }^{1}$ School of Oceanography University of Washington, Seattle WA 98195, USA

${ }^{2}$ Institute for Marine and Antarctic Studies University of Tasmania, Hobart Tasmania 7001, Australia

${ }^{3}$ College of Earth, Ocean and Atmospheric Sciences, Oregon State University, Corvallis OR 97331, USA

*Corresponding author cfuchsm1@u.washington.edu (206) 685-4196 


\begin{abstract}
Benthic chamber incubations were performed in the mid-shelf region on the Oregon shelf in June and August 2009 to measure fluxes of oxygen, nutrients, and iron and their effect on water column chemistry. Chamber oxygen and nitrate fluxes were into the sediments while silicate, iron and ammonium fluxes were out of the sediments. Benthic fluxes were similar between the two months, except that dissolved iron fluxes were higher at some sites in August. Bottom waters were consistently hypoxic (43-64 $\left.\mu \mathrm{M} \mathrm{O}_{2}\right)$ and had ammonium concentrations from 0-2.6 $\mu \mathrm{M}$ in the mid-shelf region. Given measured ammonium fluxes $\left(0.2\right.$ to $1.4 \mathrm{mmol} \mathrm{m}^{-2}$ $\mathrm{d}^{-1}$ ), we used a simple stoichiometric model for a $10 \mathrm{~m}$ bottom boundary layer to calculate that benthic fluxes only contributed $\sim 16-41 \%$ of the bottom water ammonia. Benthic oxygen fluxes (4.3 to $-12.5 \mathrm{mmol} \mathrm{O}_{2} \mathrm{~m}^{-2} \mathrm{~d}^{-1}$ ) were responsible for $\sim 38-51 \%$ of oxygen drawdown in the benthic boundary layer. In both cases, the remainder may be attributed to water column respiration. Benthic iron and nitrate fluxes have opposite effects on productivity. Iron fluxes $\left(0-71 \mu \mathrm{mol} \mathrm{m}{ }^{-2}\right.$ $\mathrm{d}^{-1}$, average: $\left.5 \mu \mathrm{mol} \mathrm{m} \mathrm{m}^{-2}\right)$ increased bottom water concentrations while nitrate was lost (-1.2 to $-2.9 \mathrm{mmol} \mathrm{m} \mathrm{m}^{-2} \mathrm{dO}_{3}^{-}$) due to denitrification. By supplying iron and consuming nitrogen, benthic diagenetic processes reinforce an iron-replete, nitrate-limited coastal ecosystem.
\end{abstract}




\section{Introduction}

Winds blowing alongshore to the south drive offshore Ekman transport and upwelling off the coasts of Washington, Oregon and California during the spring and summer (Huyer, 1983). The upwelled water contains nutrients that stimulate phytoplankton production, and, in turn, nourish a complex coastal ecosystem.

Summertime hypoxic and anoxic events leading to mortality of groundfish and benthic invertebrates have been recorded over the Oregon continental shelf in the past decade (Grantham et al., 2004; Hales et al., 2006; Chan et al., 2008). This may be due in part to decreasing oxygen concentrations with time in the oceanic water masses that feed into the California Current system (Whitney et al., 2007) and affect oxygen concentrations on the continental shelf (Grantham et al., 2004; Connolly et al., 2010). As the upwelled water often originates from depths of 100 meters or more, it is usually low in dissolved oxygen, and may be nearly hypoxic $\left(2 \mathrm{mg} / \mathrm{L} \mathrm{O}_{2} ; 62 \mu \mathrm{M}\right)$; however the occurrence of severe hypoxia requires on-shelf respiration to drive $\mathrm{O}_{2}$ to levels well below source water concentrations (Grantham et al., 2004; Hales et al., 2006; Chan et al., 2008; Connolly et al., 2010).

Upwelling off Oregon often occurs for several-day periods punctuated by shorter relaxation events during which bottom layer waters move toward the open ocean (Huyer, 1983; Hales et al., 2006). During a relaxation event, particulate organic matter from the highly productive surface waters can be transported offshore with the benthic bottom layer water, and then sink into deeper waters; this removal of POM reduces the oxygen demand in shelf waters (Hales et al., 2006). Therefore, time periods with sustained upwelling are likely to have severely 
hypoxic conditions while relaxation periods are likely to have higher oxygen concentrations (Hales et al., 2006).

Diagenetic processes in continental shelf sediments in the Pacific Northwest consume oxygen and nitrate (Devol and Christensen, 1993) and mass balances of oxygen have suggested that sediment processes contribute 50\% of the oxygen depletion in the bottom boundary layer on the Oregon and Washington shelf (Connolly et al., 2010). There are few data for benthic nutrient fluxes on the Oregon shelf ( $\mathrm{n}=9$ measurements; Berelson et al., 2013) and equally few data for benthic iron fluxes ( $\mathrm{n}=9$ measurements; Severmann et al., 2010).

Continental shelf sediments are an important source of iron to the coastal and global water column (Johnson et al., 1999; Fitzwater et al., 2003; Elrod et al., 2004; Severmann et al., 2010; Siedlecki et al., 2012). As sediment-water iron exchange is enhanced at hypoxic bottom water oxygen concentrations (Severmann et al., 2010), high benthic iron fluxes might be expected. Indeed, high concentrations of reduced iron (Fe(II)) have been found in hypoxic bottom waters of the Oregon shelf (Lohan and Bruland, 2008), suggesting a rapid input rate from sediments. Since the amount of chlorophyll and the potential for iron limitation in upwelled water correlates positively with the shelf width along the Oregon and California coast, it has been suggested that upwelling of bioavailable sediment-source iron allows phytoplankton production to consume all available nitrate (Chase et al., 2005b; Chase et al., 2007). It is possible that the ultimate source of this iron is from winter river run-off; the iron is subsequently stored in shelf sediments and ultimately released by suboxic diagenetic processes during productive summer months (Chase et al., 2007).

While upwelling of benthic-source iron may increase surface primary productivity, a net loss of fixed nitrogen in the benthos due to denitrification could potentially reduce surface 
primary productivity. In this study, we used benthic flux chambers to determine oxygen $(n=17)$, nutrient $(n=8)$ and dissolved iron fluxes $(n=10)$ across the sediment water interface on the Oregon mid-shelf, and we evaluated the effects of these fluxes on the water column using a simple model.

\section{Study Sites}

Sampling on the Oregon shelf was conducted during two cruises of the $R / V$ Wecoma in June and August 2009 (Table 1) in conjunction with a study of sediment oxygen demand using the eddy correlation technique (Reimers et al., 2012). Stations (Figure 1) were named for their proximity to the Newport Hydrographic line (NH), and coastal features known as Strawberry Hill (SH) and Heceta Head (HH) (Grantham et al., 2004; Reimers et al., 2012), and their nominal bathymetry; e.g. NH50 refers to the station near the $50 \mathrm{~m}$ isobath on the NH line. Stations were generally from the mid-shelf region. From the NH line north $\sim 100 \mathrm{~km}$, the shelf has relatively simple bathymetry, with isobaths that largely parallel the shoreline and depths that increase monotonically with distance from shore. To the south, the Heceta Bank complex, including Heceta Head, extends offshore to the southwest, significantly increasing shelf width and creating complex submarine outcroppings and a broad deep swale between the shore and the outer banks. Upwelling circulation patterns at Newport are fairly simply described as onshore at depth and offshore in surface waters, with a water-column-average southward alongshore transport. While net alongshore transport at the broader shelf of Heceta Bank is still southward with equivalent total water transport (Hales et al., 2006), mean velocities are lower and longer water retention times result from the region's circuitous recirculation patterns (Oke et al., 1999). Heceta Bank is 
a location of elevated concentrations of phytoplankton (Barth et al., 2005), zooplankton (Keister et al., 2009), and whales (Tynan et al., 2005).

While other Oregon shelf studies have shown the effects of on-shelf respiration to increase over the course of the summer (Hales et al., 2006), the upwelling season in 2009 started in early April, and the large seasonal decline in oxygen on the shelf occurred before our June cruise (Adams et al., 2013). A mooring at the SH $70 \mathrm{~m}$ isobath recorded consistently hypoxic oxygen concentrations from June to mid-August in 2009, after which time oxygen concentrations began to increase (Adams et al., 2013). During June to mid-August, oxygen concentrations at the mooring continued to have a generally decreasing trend, however, the slope of this decrease was greatly reduced (Adams et al., 2013).

\section{Methods}

\subsection{Water Column Sampling}

Near-bottom water conditions were determined using a standard CTD/rosette sensor/sampling package, deployed close in space and time to the lander deployments.

Temperature, conductivity and pressure were measured in situ with a Seabird 9+ CTD system with dual temperature and conductivity sensor pairs. During individual casts, the CTD was lowered to within $4 \mathrm{~m}$ of the seafloor, and three 10-L Niskin bottles were used to collect water for oxygen and nutrient measurements. The oxygen samples were fixed with Winkler reagents in $125 \mathrm{~mL}$ glass flasks and titrated at sea using an amperometric method (Culberson et al., 1991) for detecting the triiodide ion reaction endpoint. Bottom water nutrient samples were stored in acid-washed Nalgene ${ }^{\mathrm{TM}}$ 60-ml HDPE bottles at $-20^{\circ} \mathrm{C}$ until analyzed at Oregon State University using standard colorimetric methods (Gordon et al., 1995). 
Sediment appearance was determined qualitatively by visual inspection of sediments from sediment cores collected with a frame-mounted gravity corer (Reimers et al., 2012).

\subsection{Benthic Chamber Incubations}

The benthic lander contained a pair of 20.3 x $20.3 \mathrm{~cm}$ Teflon-lined stainless-steel flux chambers (A and B chambers) that were implanted into the sediments. The flux chambers were configured to have an exact $5 \mathrm{~cm}$ overlying water height, with remaining length of chamber walls penetrating into the sediment. This $5 \mathrm{~cm}$ value was used for flux calculations. This assumption was valid due to the sandy nature of the sediments, which prevented the lander's feet from sinking into the sediment (Table 2). If the lander did not rest perfectly level on the sediments, we would expect an error of up to $1 \mathrm{~cm}$ in chamber height. This could alter derived fluxes by a maximum of 20\%. Deployment times varied from 12 to $14 \mathrm{~h}$, including delays between landing on the bottom, chamber implantation, and lid closure. Details of the benthic lander can be found in Devol and Christensen (1993) and Tengberg et al., (2005) and only significant modifications are outlined below.

Each Teflon-lined benthic chamber was equipped with an Aanderaa model 4330 oxygen optode, a $4 \mathrm{~cm} \times 1 \mathrm{~cm}$ Teflon stir bar (stirring at $1 \mathrm{~Hz}$ and driven by a magnetically coupled stirring motor), and eight spring-actuated $50 \mathrm{~mL}$ syringes for time series samples. The oxygen optode was mounted in the flux chamber lid such that the sensing foil was flush with the lid. The syringe sampling ports were also on the lid. The oxygen optode output (0-5 volts) was recorded every $5 \mathrm{~min}$ by the control electronics for the lander. Oxygen concentrations were calculated using the manufacturer's calibration coefficients and the in situ temperature, after which corrections for salinity and pressure were applied using methods recommended by the 
manufacturer. Agreement between optode $\mathrm{O}_{2}$ values at the beginning of the chamber incubations and Winkler titrations of near-bottom waters collected with Niskin bottles was typically within the combined uncertainty of the two measurements $( \pm 1 \mu \mathrm{M}$ for the titrations, and $\pm 3 \mu \mathrm{M}$ for the optode) with the exception of one deployment (HH80 in August).

Oxygen fluxes were calculated from a linear fit to the first 180 minutes of electrode data after the chamber lid closed. Because oxygen concentration changes were not strictly linear during most chamber deployments (Figure 2), the oxygen time series were also fit with a second order polynomial that was differentiated to solve for the flux at time zero (polynomial fits all had $\mathrm{R}^{2}>0.98$ in August and $>0.96$ in June). These values were $\sim 1.5 \mathrm{mmol} \mathrm{m} \mathrm{m}^{-1}$ larger than those determined by a linear fit to the first 180 minutes after closing the lid of the chamber (Table S1). However, this difference between calculations is significantly smaller than the $3 \mathrm{mmol} \mathrm{m} \mathrm{d}^{-1}$ average difference between chamber deployments. We used the linear fit fluxes to be able to compare the former to other studies and to the linear regressions of the discrete nutrient samples.

\subsection{Discrete Sampling in the Chamber}

Discrete samples were collected from each chamber by 5 syringes that each withdrew 50 $\mathrm{mL}$ from the chambers at designated intervals after the lid closed. Water removed by sampling was replaced by external bottom water drawn through a $25 \mathrm{~cm}$ section of $1 / 8$ inch i.d. nylon tubing. The syringes for the trace-metal samples were acid-washed. Fluxes of nutrients and iron were nominally calculated from regression slopes of the first 3-4 time points, within 6 hours of the lid closure to record initial fluxes before oxygen concentrations reached suboxic conditions.

The protocols for isolating and allocating the syringe-drawn samples were slightly different in June and August. In June, one set of samples (from chamber B) was used for nutrient analyses and the other (from chamber A) exclusively for iron. In August, samples for iron were 
taken from both chamber A and chamber B, allowing flux estimates from both chambers; five syringes were used to collect and capture Fe time-series samples from Chamber A, while for chamber B, $15 \mathrm{~mL}$ Teflon sample loops filled with degassed distilled water were inserted before three of the syringes. Samples drawn into these loops were designated strictly for iron analyses. When a syringe was activated, $15 \mathrm{~mL}$ of distilled water from the tubing and loop and $35 \mathrm{~mL}$ of overlying water were drawn into the syringe, flushing the Teflon loop such that it contained only undiluted sample water. This use of the Teflon loops in August did not seem to affect the derived iron fluxes as the concentration time series from both chambers were found to be in the same range. No Teflon sample loops were present for the nutrient samples. However, the tubes connecting the syringes to the chamber were filled with distilled water $(1.4 \mathrm{~mL}$ in June and $4 \mathrm{~mL}$ in August). The volumes of nutrient and iron samples were measured and concentrations were corrected for this addition of distilled water. The correction for distilled water was nearly negligible for June, but larger in August; the change in concentration was $\sim 5 \mu \mathrm{M} \mathrm{Si} ; 2 \mu \mathrm{M}$ $\mathrm{NO}_{3}{ }^{-} ; 0.4 \mu \mathrm{M} \mathrm{NH}_{4}{ }^{+} ; \sim 0.04 \mu \mathrm{M} \mathrm{NO}_{2}^{-}$in August.

\subsection{Chemical analysis of chamber samples}

Nutrient samples from the benthic flux chambers were filtered through a $0.45 \mu \mathrm{m}$ GFF filter and then frozen and stored at $-20^{\circ} \mathrm{C}$ in scintillation vials until analysis. Analyses were performed at the University of Washington Marine Chemistry Laboratory using a Technicon AAII system as described by the World Ocean Circulation Experiment (WOCE) Hydrographic Program protocol (Gordon et al., 1995). In June, two syringes were triggered at the same time on ten occasions to get a sense of measurement uncertainty. Average standard-deviations between duplicate syringe samples from the same benthic lander chamber were $1.4 \mu \mathrm{M}$ for $\mathrm{NO}_{3}{ }^{-}, 0.3 \mu \mathrm{M}$ for $\mathrm{NH}_{4}{ }^{+} ; 0.2 \mu \mathrm{M}$ for $\mathrm{PO}_{4}{ }^{3-}$; and $5.3 \mu \mathrm{M}$ for $\mathrm{H}_{4} \mathrm{SiO}_{4}$. Time-zero lander nutrient syringes, which 
sampled water at $<5 \mathrm{~cm}$ above the sediments, and near-bottom Niskin-bottle samples (Table 1), from $\sim 4$ meters above the sediments, yielded differences of $-0.3 \pm 1.2 \mu \mathrm{M}$ for $\mathrm{NO}_{3}{ }^{-}, 1.1 \pm 1.0 \mu \mathrm{M}$ for $\mathrm{NH}_{4}{ }^{+} ;-0.3 \pm 0.4 \mu \mathrm{M}$ for $\mathrm{PO}_{4}{ }^{3-}$; and $-0.1 \pm 5.4 \mu \mathrm{M}$ for $\mathrm{H}_{4} \mathrm{SiO}_{4}$. Niskin-bottle samples were generally significantly lower for ammonium. Due to the different sampling depths of the two sampling techniques, the differences in ammonium concentrations are assumed to be real.

Samples for dissolved iron were filtered immediately after recovery through acid-washed, $0.45 \mu \mathrm{m}$ polypropylene syringe filters. Filtered samples were collected in acid-washed polyethylene bottles, and acidified with $4 \mathrm{~mL} / \mathrm{L}$ of $6 \mathrm{M}$ double-distilled $\mathrm{HCl}$. Iron was determined by flow injection analysis with colorimetric detection after oxidation of $\mathrm{Fe}$ (II) with $\mathrm{H}_{2} \mathrm{O}_{2}$ (Lohan et al. 2006). Samples were stored acidified for at least 24 hours prior to analysis. Accuracy was confirmed by analysis of the NASS- 5 seawater reference material. Filter-blanks, assessed by filtering Milli-Q water through the syringe filters, were insignificant.

\subsection{Available Data}

We have complete flux data sets at stations NH50, SH80, HH80, and HH110 in June, and NH50, NH80, and HH80 in August. We also have oxygen optode data for HH140 and HH150 in August. Oxygen flux data from SH80 (J5 and A7) and NH80 (A6) were previously published in Reimers et al. (2012). The oxygen flux from the June HH80 (deployment J3) was not used in Reimers et al (2012) due to a transitory increase in oxygen during the deployment (Figure S1). However, the slope and intercept describing the oxygen flux is similar before and after this transitory increase, which implies a bubble caught next to the oxygen probe during deployment. The oxygen flux described here for June HH80 was calculated using only the first 100 minutes of data. In the HH80 deployment in August (A3) initial oxygen concentrations from the optode in the chamber $(<5 \mathrm{~cm}$ from the bottom) were $19 \mu \mathrm{M}$ lower than values from $4 \mathrm{~m}$ above the 
bottom. However, both oxygen concentrations are within the range of measurements from other stations and so both are assumed to be valid.

\section{Results}

\subsection{Cruise conditions}

Chamber incubations were performed along cross-shelf sections off the Oregon coast in June and August 2009 (Figure 1). Upwelling favorable winds (to the south) were present during the second half of the June cruise. During the August cruise the winds shifted between upwelling favorable (to the south), not favorable (to the north), and back to favorable again but were generally weak (wind data from NOAA buoy 46050; http://www.ndbc.noaa.gov).

Bottom water conditions were fairly consistent spatially during each cruise for the depths where chambers were deployed (Table 1). In June, average bottom waters for the mid-shelf region $(50-150 \mathrm{~m})$ were cold $\left(T=7.34 \pm 0.17^{\circ} \mathrm{C}\right)$, salty $(S=33.87 \pm 0.07)$, dense $\left(\sigma_{\theta}=26.48 \pm 0.08\right)$, and $\mathrm{O}_{2}$ poor $(49 \pm 7 \mu \mathrm{M})$ and nutrient rich $\left(\left[\mathrm{NO}_{3}{ }^{-}\right]=34.0 \pm 1.4 ;\left[\mathrm{NH}_{4}{ }^{+}\right]=0.8 \pm 0.4 ;\left[\mathrm{PO}_{4}{ }^{3-}\right]=\right.$ 3.02 \pm 0.10 ; and $\left[\mathrm{H}_{4} \mathrm{SiO}_{4}\right]=58 \pm 12$; all in $\mu \mathrm{M}$ ). In August, bottom waters were slightly warmer $\left(\mathrm{T}=7.71 \pm 0.17^{\circ} \mathrm{C}\right)$ and of similar salinity $(\mathrm{S}=33.87 \pm 0.06)$ and slightly lower density $\left(\sigma_{\theta}=26.43 \pm 0.04\right)$. August $\mathrm{O}_{2}$ concentrations were slightly greater $(55 \pm 9 \mu \mathrm{M})$, and nutrient concentrations not significantly different $\left(\left[\mathrm{NO}_{3}{ }^{-}\right]=33.4 \pm 1.9 ;\left[\mathrm{NH}_{4}{ }^{+}\right]=1.1 \pm 1 ;\left[\mathrm{PO}_{4}{ }^{3-}\right]=\right.$ 2.99 \pm 0.10 ; and $\left[\mathrm{H}_{4} \mathrm{SiO}_{4}\right]=61 \pm 7$; all in $\left.\mu \mathrm{M}\right)$, than in June.

Bottom water iron concentrations were measured only at stations HH80 and HH110 during the June cruise. The concentrations ( 22 and $26 \mathrm{nM}$, respectively) were similar to those 
observed by Lohan and Bruland (2008) and slightly higher than initial concentrations measured in the associated chamber incubations (16 and $21 \mathrm{nM}$, respectively).

Deep-water oxygen and nutrient concentrations showed only modest correlation, as might be expected for the small dynamic ranges of these parameters. Most of the nutrients did not correlate statistically $(\mathrm{p}>0.1)$. However, combined June and August bottom water ammonium concentrations were inversely correlated with nitrate concentrations in the mid-shelf region $(50 \mathrm{~m}-150 \mathrm{~m})\left(\left[\mathrm{NH}_{4}{ }^{+}\right]=-0.4358 *\left[\mathrm{NO}_{3}{ }^{-}\right]+15.66, \mathrm{R}^{2}=0.75 ; \mathrm{p}\right.$ value $\left.=1 \mathrm{E}-3\right)$.

Sediment grain size was only qualitatively assessed (Table 2), but results were consistent with previous observations of the Washington and Oregon shelf seafloor, with the coarsest sediments inshore (Kachel and Smith, 1989 and references therein).

\subsection{Benthic Fluxes}

Oxygen and nitrate fluxes were always negative, i.e., into the sediments, , while ammonium, iron (with the exception of one statistically insignificant result) and silicate fluxes were always positive (Table 3; Figure 2; Figures S2-S4). Phosphate fluxes ( Figure 2) were rarely significantly different from zero. Oxygen fluxes averaged $-8 \mathrm{mmol} \mathrm{m}^{-2} \mathrm{~d}^{-1}$ with $\pm 3 \mathrm{mmol}$ $\mathrm{m}^{-2} \mathrm{~d}^{-1}$ variability among deployments. Oxygen fluxes were always at least two times greater than corresponding nitrate fluxes (average of $-2.0 \mathrm{mmol} \mathrm{m}^{-2} \mathrm{~d}^{-1}$ with $\pm 0.5 \mathrm{mmol} \mathrm{m} \mathrm{d}^{-1}$ variability between chambers), suggesting an important role for aerobic metabolic processes despite hypoxic bottom water conditions. In August ammonia fluxes were linear for the first 5 or so hours, after which time ammonia concentrations decreased in many of the deployments (Figure S3). Ammonium fluxes, averaging $0.6 \mathrm{mmol} \mathrm{m}^{-2} \mathrm{~d}^{-1}$ out of the sediments (with \pm 0.4 mmol $\mathrm{m}^{-2} \mathrm{~d}^{-1}$ variability among deployments), were significantly smaller than the nitrate fluxes into the sediments. Silicate fluxes had a 10 fold range $\left(1.2-11 \mathrm{mmol} \mathrm{m}^{-2} \mathrm{~d}^{-1}\right)$, but iron fluxes were 
the most variable, with values ranging from $\sim 0$ to $71 \mu \mathrm{mol} \mathrm{m} \mathrm{m}^{-2} \mathrm{~d}^{-1}$ This variability was evident even between chambers for the same deployment, with values of 19 and $71 \mu \mathrm{mol} \mathrm{m} \mathrm{m}^{-2}$ seen in chambers A and B, respectively at HH80 in August (Table 3). Similar to bottom water concentrations, the benthic fluxes of oxygen, nitrate, ammonia, silicate and iron did not correlate with each other between chamber deployments ( $p>0.05)$.

At most stations, oxygen fluxes were comparable between chambers at the same deployment with an average difference of $1.3 \mathrm{mmol} \mathrm{m}^{-2} \mathrm{~d}^{-1}$ (excluding HH140). However, these chamber to chamber differences are greater than error calculated from regressions and could be due to heterogeneity in the contribution of macrofaunal respiration and irrigation (Glud and Blackburn, 2002), or small differences in assumed chamber height above the sediments.

\section{Discussion}

\subsection{Advective versus diffusive fluxes}

Most benthic flux measurements made in this study of the Oregon shelf were made at sites with sandy or permeable sediments (Reimers et al., 2012). This situation differs from the Washington Shelf, which has a muddy zone from 50 meters depth to 130 meters due to deposition of fine sediments originating from Columbia River (Kachel and Smith, 1989). In muddy sediments, fluxes are driven primarily by molecular diffusion or by macrobenthic irrigation while in sandy sediments, bottom currents may interact with topography to push water through the sediments. The importance of this advective flux depends on the permeability of the sediments, strength of bottom motions and the extent of the topography (Huettel et al., 1998; Precht et al., 2004). 
Eddy correlation often produces larger flux estimates than chamber incubations for sandy sediments because the eddy correlation technique is better suited to capture the effects of pore water advection (Berg and Huettel, 2008). However, at two 80 m stations on the Oregon shelf, oxygen fluxes determined both by eddy correlation and benthic chambers were found to be similar (Reimers et al., 2012). This similarity remains when all chamber data is included (Figure 3), suggesting that pore-water advective fluxes were not large in the mid-shelf, at least during the summer months.

The shallower, NH30 station was the exception. We could not obtain consistent chamber fluxes at $\mathrm{NH} 30$ on either cruise as oxygen concentrations both increased and decreased during the chamber incubations. This could be consistent with advective flows ventilating the chambers or a repeated $(n=4)$ poor bottom seal with the sand. Eddy correlation fluxes at this shallow site measured in four months in the summer of 2009 varied from -10 to $-30 \mathrm{mmol} \mathrm{m} \mathrm{d}^{-1}$ and indicated advective transport of oxygen (McCann-Grosvenor et al., 2014).

\subsection{Comparison to other sites}

Primary productivity is historically higher on the Washington shelf compared to Oregon even though the upwelling winds are stronger off Oregon (Hickey and Banas, 2003). Perhaps this greater primary productivity, results in the historically more prevalent hypoxia on the Washington shelf (Connolly et al., 2010). However, our Oregon shelf fluxes are similar to previous chamber measurements on the southern Oregon shelf as well as California and Washington shelves (Fig. 3). However, our Oregon shelf fluxes are similar to previous chamber measurements on the southern Oregon shelf as well as California and Washington shelves

(Figure 3). Our nitrate fluxes were higher in magnitude than off California although still into the sediments (Figure 3). Dissolved iron fluxes on the California shelf depend on bottom water $\mathrm{O}_{2}$, 
with rates of $11.0 \mu \mathrm{mol} \mathrm{m} \mathrm{m}^{-2} \mathrm{~d}^{-1}$ when bottom water $\mathrm{O}_{2}$ was $>18 \mu \mathrm{M}$, but increasing at lower $\mathrm{O}_{2}$ concentrations (Elrod et al., 2004). Benthic chamber incubations on the shelf near the Umpqua River in Southern Oregon yielded atypically high iron fluxes from 21-97 $\mu \mathrm{mol} \mathrm{m} \mathrm{m}^{-2} \mathrm{~d}^{-1}$ which were hypothesized to result from deposition of iron-rich sediments during river flood events (Severmann et al., 2010), Our highest iron flux $\left(103 \mu \mathrm{mol} \mathrm{m} \mathrm{d}^{-1}\right)$ was also obtained in the general vicinity of the Umpqua River. The dissolved iron fluxes measured here were at the low range of results available for the US West coast margin.

Benthic fluxes on the continental shelf bordering the US West coast differ from other coastal sediments with different oxygen regimes, particularly in regard to $\mathrm{N}$ fluxes. In contrast to Oregon shelf, nitrate fluxes were generally out of the sediments in chamber incubations in the Gulf of Cadiz, the Skagerrak, and Port Phillip Bay, Australia (Ferron et al., 2009; Hall et al. 1996; Berelson et al., 1998). Like Oregon, ammonium fluxes were also out of the sediments in Port Phillip Bay, Australia and in the Gulf of Cadiz when the organic carbon content of the sediments was high (Ferron et al., 2009; Berelson et al., 1998). Nitrogen fluxes in coastal sediments around the world thus appear to be quite variable, and are likely sensitive to variations in local productivity and bottom-water $\mathrm{O}_{2}$ and nitrate concentrations. Their similarity along the Western US Continental shelf is likely due to the circulation regime of the California current and relatively high primary production. Additionally, the entire US West coast is affected by upwelling of high nutrient, low oxygen waters sourced from the North Pacific.

\subsection{Denitrification in Shelf Sediments}

Continental shelf sedimentary denitrification is an important loss term for the marine combined nitrogen budget (Christensen et al., 1987; Codispoti et al. 2007). Nitrate fluxes into the sediment provide a minimum estimate of denitrification rates, but Devol and Christensen (1993) 
found that $\mathrm{N}_{2}$ gas fluxes out of the sediment were greater than nitrate fluxes into the sediment on the Washington shelf. Ammonium is also produced from organic matter degradation during both aerobic and anaerobic respiration. Larger $\mathrm{N}_{2}$ fluxes could result from within sediment nitrification of remineralized ammonium coupled to denitrification or from the autotrophic anammox process, which has been found in deeper sediments off Washington (Engstrom et al., 2009). The observation that the nitrate flux into the sediments was greater than the ammonium plus nitrite flux out of the sediments (Table 3) indicates that the Oregon shelf is a net sink of dissolved inorganic fixed $\mathrm{N}$.

We used a nitrogen and oxygen mass balance to estimate a $\mathrm{N}_{2}$ gas flux from the Oregon sediments. Assuming an elemental stoichiometry of organic matter Anderson (1995), balanced equations for aerobic carbon oxidation (Eq 1) and denitrification (Eq 2) read as follows (Paulmier et al., 2009):

Eq 1: $\mathrm{C}_{106} \mathrm{H}_{175} \mathrm{O}_{42} \mathrm{~N}_{16} \mathrm{P}+118 \mathrm{O}_{2} \rightarrow 106 \mathrm{CO}_{2}+16 \mathrm{NH}_{3}+\mathrm{H}_{3} \mathrm{PO}_{4}+62 \mathrm{H}_{2} \mathrm{O}$

Eq 2: $\mathrm{C}_{106} \mathrm{H}_{175} \mathrm{O}_{42} \mathrm{~N}_{16} \mathrm{P}+94.4 \mathrm{HNO} \rightarrow 106 \mathrm{CO}_{2}+16 \mathrm{NH}_{3}+\mathrm{H}_{3} \mathrm{PO}_{4}+109.2 \mathrm{H}_{2} \mathrm{O}+47.2 \mathrm{~N}_{2}$. Given the following relationships between benthic fluxes, aerobic carbon oxidation (Ac), carbon oxidized by denitrification ( $\mathrm{Nc}$ ), and ammonia production (AP), $\mathrm{N}_{2}$ gas production can be obtained according to Hartnett and Devol (2003).

Eq 3: $A P=\frac{16}{106} A c+\frac{16}{106} N c$

Eq 4: $O_{2, F i u x}=\frac{11 H}{1 H_{t}} A c+2\left(A P+N H_{1, y i u x}^{+}\right)$

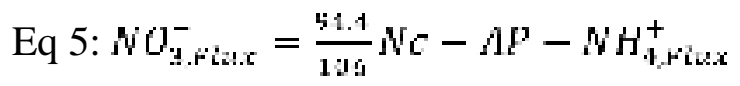


Eq 6: $N_{2}=\frac{47.2}{106} N c$

where oxygen consumed in ammonia oxidation is $2\left(\mathrm{AP}-\mathrm{NH}_{4}{ }^{+} \mathrm{Flux}\right)$. Implicit in this calculation is the assumption that other reduced products of carbon oxidation, (e.g. sulfide) are also reoxidized by oxygen (Canfield et al., 1993). The calculated $\mathrm{N}_{2}$ production rates, i.e. denitrification rates varied from 1.5 to $4.4 \mathrm{mmol} \mathrm{N} \mathrm{m}^{-2} \mathrm{~d}^{-1}$ (average $2.7 \pm 1.0 \mathrm{mmol} \mathrm{N} \mathrm{m}^{-2} \mathrm{~d}^{-1}$; Table 4). This range is quite similar to measured $\mathrm{N}_{2}$ fluxes from the Washington shelf (2.2- 4.6 mmol N m${ }^{-2} \mathrm{~d}^{-1}$; Devol and Christensen, 1993) and higher than calculated denitrification rates from California (Berelson et al., 1996). The lander deployments from $80 \mathrm{~m}$ offshore of Newport and Heceta Head in August were interesting because all the ammonium produced in the sediments was returned to the water column (Table 4). Ratios of carbon oxidation by oxygen to that by nitrate (Ac/Nc) are typically 3-150 in oxygenated ocean sediments (Jahnke et al., 1982), but off Oregon the Ac/Nc ratio was low $\sim 2$ for most of the stations (Table 4). When flux data from the California margin (Berelson et al., 1996) were used in this model, Ac/Nc ratios were 4 5 while ratios for the Washington shelf (Devol and Christensen, 1993) were similar to those in this study, 2-3. Denitrification appears to be a particularly important in shelf sediment influenced by the California current system, probably due to the seasonally hypoxic bottom waters and high carbon loading resulting from upwelling.

\subsection{Effect of Benthic Respiration on Oxygen and Ammonia concentrations}

Benthic fluxes and bottom water concentrations did not correlate for any of the chemical species studied here ( $p>0.05)$. As the bottom water on the shelf is continually in motion, the measured nutrient concentrations may not reflect local benthic fluxes, but rather an accumulation of previous fluxes and reactions along the flow path. To calculate the effect of the benthic fluxes on bottom boundary layer (BBL) chemistry, we need to know the residence time and the volume 
of the BBL water. Using mooring data, residence time of water on the shelf at $\mathrm{SH} 70 \mathrm{~m}$ isobath was estimated to be up to a month (Adams et al., 2013), and examination of the CTD density profiles suggest that the benthic boundary layer during the our cruises was about $11 \mathrm{~m}$ thick at NH80, $5 \mathrm{~m}$ at NH50 and 9 meters at SH80, which is consistent with prior observations (Perlin et al., 2005). However, the effect of benthic oxygen flux on the BBL is complicated because respiration occurs both in the sediments and in the water column. Rates of oxygen consumption in the water column were measured at SH $70 \mathrm{~m}$ in 2009 and varied between 0.7 and $2.2 \mu \mathrm{M} \mathrm{d}^{-1}$ $\mathrm{O}_{2}$ (Adams et al., 2013). In addition to respiration, these rates should also include oxygen consumption by ammonia oxidation to nitrite and nitrate. Although there are no ammonia oxidation rates for the Oregon shelf waters, rates up to $200 \mathrm{nM} \mathrm{d}^{-1}$ have been detected at $150 \mathrm{~m}$ in the California Current off of central California (Santoro et al., 2010). Generally ammonia oxidation rates in marine water columns are significantly lower (Horak et al., 2013; Newell et al., 2011; Beman et al., 2012), so $200 \mathrm{nM} \mathrm{d}^{-1}$ is a reasonable upper range for ammonia oxidation.

We examined the importance of benthic oxygen and ammonia fluxes on BBL concentrations by combining the following equations to collectively constrain water residence time, water column respiration and ammonia oxidation. The residence time $(\tau)$ of the water on the shelf is related to the difference between oxygen concentrations at the same density at offshore and on-shelf sites and the three sinks for oxygen: benthic respiration, water column respiration, and ammonia oxidation.

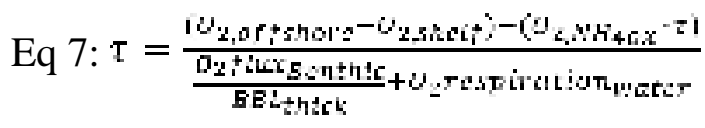

Offshore oxygen concentrations from just beyond the shelf break are available for a time period within a week of the August cruise along the same latitude as our NH and SH stations (unpublished data, BH). The differences between offshore and onshelf oxygen concentrations at 
SH80, NH80 and NH50 were 32, 44 and $58 \mu \mathrm{M}$ respectively when density surfaces were traced across the shelf (densities seen in Table 1). We used the average benthic oxygen flux of -8.0 $\mathrm{mmol} \mathrm{m} \mathrm{m}^{-2} \mathrm{~d}^{-1}$

While consuming oxygen, respiration produces ammonia. Given the stoichiometry of organic matter from Eq 1 and the residence time, we calculated ammonia oxidation rates.

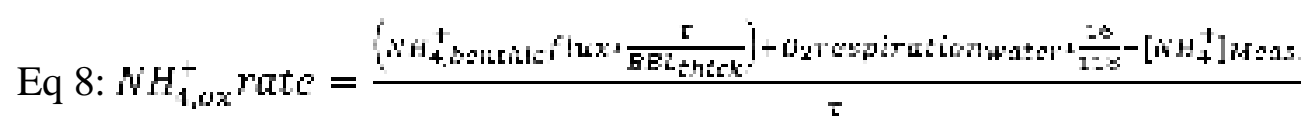

For each residence time, oxygen consumed during ammonia oxidation was calculated. These values were subtracted from the differences between offshore and onshelf oxygen concentrations, slightly changing the calculated residence time (Eq 7). Residence times were corrected using an iterative process until oxygen consumption values stabilized. Oxygen utilized by ammonia oxidation was $<20 \%$ of oxygen consumption (Fig 4 ). The benthic ammonium flux was $+0.6 \mathrm{mmol} \mathrm{m}^{-2} \mathrm{~d}^{-1}$, and ammonium measured in the bottom waters at these stations were 0 $2.5 \mu \mathrm{M}$. Given our measured $\mathrm{NH}_{4}{ }^{+}$fluxes, ammonium concentrations, bottom water $\mathrm{O}_{2}$ and fluxes and using Eq 7 and Eq 8, we estimated residence time and ammonia oxidation rate as a function water-column respiration rates. In the model, as the water column respiration increases and the measured benthic fluxes and bottom water concentrations of $\mathrm{O}_{2}$ and $\mathrm{NH}_{4}{ }^{+}$remain constant, the calculated residence time of the water decreases and water column ammonia oxidation increases (Figure 4). We then look at the model space where water column respiration, ammonia oxidation and residence time are all within published ranges and calculate the percent ammonia production from the benthos in that restricted space (Figure 4).

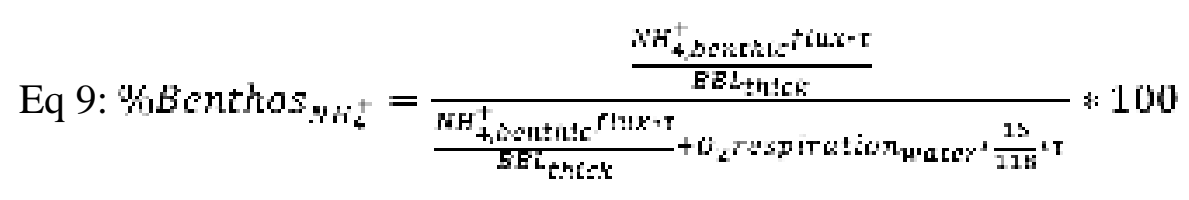


Modeled data indicates a water residence time $>14$ days with $16-41 \%$ of ammonium production from the benthos, which was oxidized in the water column at a rate between 93-209 $\mathrm{nM} \mathrm{d}^{-1}$. Correspondingly, the benthos accounted for $38-51 \%$ of the oxygen drawdown (Table 5 and Figure 4), which is consistent with Connolly et al (2010)'s estimate of 50\% of respiration due to benthic processes. The sensitivity of the model was tested by shifting various parameters within the measured variability and results were found to be robust (Table S2). The model suggests that effect of benthic oxygen and ammonium fluxes on the measured water column concentrations was significant, but water column respiration was generally the dominant contributor (Figure 4).

On the Oregon shelf we consistently found $\mathrm{NH}_{4}{ }^{+}$in the bottom waters. High ammonium concentrations (up to $4.0 \mu \mathrm{M}$ ) were found in the near bottom waters at the most inshore station (NH30), and ammonium concentrations also reached $2.6 \mu \mathrm{M}$ in the mid-shelf region (Figure 1). In most of the ocean, all remineralized ammonium is rapidly oxidized. Ammonium concentrations up to $10 \mu \mathrm{M}$ have been found in bottom water in the Bering Sea; this is likely due to inhibition of nitrification by low temperatures $\left(-1\right.$ to $5^{\circ} \mathrm{C}$; Mordy et al., 2010). However, neither temperature nor oxygen concentrations were low enough to affect ammonia oxidation rates in Oregon bottom water (Grundle and Juniper, 2011). In fact, the ammonia oxidation rates calculated here (Table 5) are reasonable, and do not indicate any inhibition of ammonia oxidation. Respiration may just produce more ammonia than the oxidizers can utilize.

\subsection{Effect of Iron and Nitrate fluxes on Biological Productivity}

Benthic dissolved iron fluxes have been correlated with carbon oxidation rates (Elrod et al., 2004) and bottom water oxygen concentrations (Severmann et al., 2010). Using the relationship of $0.68 \mu \mathrm{mol} \mathrm{Fe} / \mathrm{mmol}$ carbon oxidation from Elrod et al (2004), one would predict 
from our average total carbon oxidation rate a flux of $5.4 \mu \mathrm{mol} \mathrm{m} \mathrm{d}^{-1} \mathrm{Fe}$ for the Oregon shelf. Our average measured flux was $5.1 \pm 10 \mu \mathrm{mol} \mathrm{m} \mathrm{d}^{-1}$, which is similar, although the variability was extreme. Nevertheless, dissolved iron fluxes did not correlate with either carbon oxidation or near-bottom oxygen concentrations (Figure 1: Tables 3 and 4) or with sediment type (Tables 2 and 3).

The combination of $\mathrm{N}$ removal by denitrification and benthic iron release have been suggested as mechanisms to prevent Fe-limitation in this system. To examine the potential effect of benthic processes on the productivity of upwelled water, we assumed that the bottom boundary layer had a residence time over the shelf of three weeks and that it was $10 \mathrm{~m}$ thick. Total dissolved iron concentrations were between 9-42 nM (Lohan and Bruland, 2008; Chase et al. 2005; Table 1). Ideally, dissolved iron fluxes would then increase iron concentrations by 0.5 $\mathrm{nM} \mathrm{d}^{-1}$ or $11 \mathrm{nM}$ in three weeks, which is an increase of $20-50 \%$. In reality, some of this iron will oxidize and precipitate back out of the water column (Chase et al. 2005). Given the same BBL assumptions, nitrate concentrations should decrease by $0.2 \mu \mathrm{M} \mathrm{d}^{-1}$ or by $3.7 \mu \mathrm{M}$ over three weeks. However, ammonium concentrations would increase by $0.06 \mu \mathrm{M} \mathrm{d}^{-1}$ or $1.2 \mu \mathrm{M}$ in three weeks, counteracting part of the nitrate decrease. As the highest boundary layer nitrate concentrations are about $35 \mu \mathrm{M}$ (Table 1), the total inorganic N present would decrease by only $6 \%$. The percent increase of dissolved iron is greater than the percent decrease in fixed nitrogen. Coastal diatoms typically contain a cellular Fe: $\mathrm{N}$ ratio of $\sim 0.33 \mathrm{nmol}: \mu \mathrm{mol}$ (Bruland et al. 2001). Boundary layer $\mathrm{Fe}$ and $\mathrm{NO}_{3}{ }^{-}$were present in a ratio of $\sim 20 \mathrm{nM}$ to $35 \mu \mathrm{M}$ respectively, or $\sim 0.6 \mathrm{nmol}: \mathrm{mol}$. Consequently, there was sufficient Fe present to support full consumption of the $\mathrm{N}$, if BBL water ultimately reached the surface. The direction of benthic fluxes also should 
increase Fe: $\mathrm{N}$ ratios over time. By supplying iron and consuming nitrogen, benthic diagenetic processes reinforce an iron-replete, nitrate-limited coastal ecosystem (Chase et al. 2005; 2007).

\section{Conclusions}

This study doubled the number of benthic nutrient and iron fluxes from the Oregon midshelf region. Despite the sandy sediments, benthic fluxes were similar to those observed in muddy sediments on the California and Washington shelves. Bottom waters were consistently hypoxic (43-64 $\mu \mathrm{M} \mathrm{O}_{2}$ ), and calculations indicated that benthic fluxes could be responsible for $38-51 \%$ of oxygen drawdown on the shelf. High ammonium concentrations $(0-2.6 \mu \mathrm{M})$ were found in the mid-shelf region, which was surprising because in most of the ocean, all remineralized ammonium is oxidized. Given measured ammonium fluxes, we calculated that benthic fluxes only could contribute $16-41 \%$ of the bottom water ammonia production with the remainder due to water column respiration.

In the Oregon and Washington shelf region, the ratio of carbon oxidized by oxygen to that oxidized by nitrate was low (2 to 3 ) compared to more-oxygenated ocean sediments. Denitrification appears to be a particularly important in shelf sediments in the California current system, due to the seasonally hypoxic bottom waters. Benthic iron and nitrate fluxes have opposite effects on productivity; benthic fluxes increased bottom water iron concentrations while nitrate was lost due to sediment denitrification.

\section{Acknowledgements}

We would like to thank Wendi Ruef and Bonnie Chang for assistance with the benthic chamber lander both before and during the cruise, and Kathy Krogslund for running chamber nutrient samples. Chris Holm and Hannah Groshong assisted with iron sampling and analysis. We would 
also like to thank the captain and crew of the R/V Wecoma. Funding was provided by NSF grants OCE 0628391 and OCE 1029316 to AHD, OCE 0726984 to CER, and NSF grant 0628700 to $\mathrm{ZC}$ and $\mathrm{BH}$. 


\section{References}

Adams, K.A., Barth, J.A., Chan F., 2013. Temporal variability of near-bottom dissolved oxygen during upwelling off central Oregon. J. Geophys. Res. Oceans 118, 4839-4854.

Anderson, L.A., 1995. On the hydrogen and oxygen content of marine phytoplankton. Deep-Sea Res I 42, 1675-1680.

Barth, J.A., Pierce, S.D., Castelao, R.M., 2005. Time dependent, wind-driven flow over a shallow midshelf submarine bank. J. Geophys. Res.110, C10S05.

Beman, J.M., Popp, B.N., Alford, S.E., 2012. Quantification of ammonia oxidation rates and ammonia-oxidizing archaea and bacteria at high resolution in the Gulf of California and eastern tropical North Pacific Ocean. Limnol. Oceanogr. 57, 711-726.

Berelson, W.M., McManus, J., Coale, K.H., Johnson, K.S., Kilgore, T., Burdige, D., Pilskain, C., 1996. Biogenic matter diagenesis on the sea floor: A comparison between two continental margin transects. J. Mar. Res. 54, 731-762.

Berelson, W.M., Heggie, D., Longmore, A., Kilgore, T., Nichoson, G. and Skyring, G., 1998. Benthic nutrient recycling in Port Phillip Bay, Australia. Estuarine, Coastal and Shelf Science 46, 917-934.

Berelson, W.M., McManus, J., Severmann, S., Reimers, C.E., 2013. Benthic flux of oxygen and nutrients across Oregon/California shelf sediments. Cont Shelf Res 55, 66-75.

Berg, P., Huettel, M., 2008. Monitoring the Seafloor Using the Noninvasive Eddy Correlation Technique: Integrated Benthic Exchange Dynamics. Oceanography 21, 164-167.

Bruland, K.W., Rue, E.L., Smith, G.J., 2001. Iron and macronutrients in California coastal upwelling regimes: Implications for diatom blooms. Limnol. Oceanogr. 46, 1661-1674.

Canfield, D.E., Jorgensen, B.B., Fossing, H., Glud, R., Gundersen, J., Ramsing, N.B., Thamdrup, B., Hansen, J.W., Nielsen, L.P., Hall, P.O.J., 1993. Pathways of organic carbon oxidation in three continental margin sediments. Mar. Geol.113, 27-40.

Chan, F., Barth, J.A., Lubchenco, J., Kirincich, A., Weeks, H., Peterson, W.T., Menge, B.A., 2008. Emergence of anoxia in the California Current large marine ecosystem. Science 319, 920.

Chase, Z., Hales, B., Cowles, T., 2005. Distribution and variability of iron input to Oregon coastal waters during the upwelling season. J. Geophys. Res. 110, C10S12.

Chase, Z., Johnson, K. S., Elrod, V. A., Plant, J. N., Fitzwater S. E., Pickell L., Sakamoto C. M. 2005b, Manganese and iron distributions off central California influenced by upwelling and shelf width, Mar. Chem., 95, 235-254.

Chase, Z., Strutton, P.G., and Hales B., 2007. Iron links river runoff and shelf width to phytoplankton biomass along the U.S. West Coast. Geophys. Res. Lett. 34, L04607.

Christensen, J.P., Smethie, W.M., and Devol., A.H. (1987) Benthic nutrient regeneration and denitrification of the Washington shelf. Deep Sea Research A 34, 1027-1047.

Connolly, T.P., Hickey, B.M., Geier, S.L., Cochlan, W.P., 2010. Processes influencing seasonal hypoxia in the northern California Current System. J. Geophys. Res. 115, C03021.

Codispoti, L., 2007. An oceanic fixed nitrogen sink exceeding $400 \mathrm{Tg} \mathrm{Na}-1$ vs the concept of homeostasis in the fixed-nitrogen inventory. Biogeosciences 4, 233-253.

Culberson, C.H., Knapp, G., Stalcup, M.C., Williams, R.T., Zemlyak F., 1991, A comparison of methods for the determination of dissolved oxygen in sea water. WHP Office Report, WHPO-91-2.

Devol, A.H., Christensen, J.P., 1993. Benthic fluxes and nitrogen cycling in sediments of the continental margin of the eastern North Pacific. J. Mar. Res. 51, 345-372. 
Diaz, R.J., Rosenberg, J., 1995. Marine benthic hypoxia: A review of its ecological effects and the behavioral responses of benthic macrofauna. Oceanogr. Mar. Biol. 33, 245-303.

Elrod, V.A., Berelson, W.M., Coale, K.H., Johnson, K.S., 2004. The flux of iron from continental shelf sediments: A missing source for global budgets. Geophys Res Lett 31, L12307.

Engstrom. P., Penton, C.R., Devol, A.H. 2009. Anaerobic ammonium oxidation in deep-sea sediments off the Washington Coast. Limnology and Oceanography 54, 1643-1652.

Ferron, S., Alonso-Perez, F., Anfuso, E., Murillo, F.J., Ortega, T., Castro, C.G., Forja, J.M., 2009. Benthic nutrient recycling on the northeastern shelf of the Gulf of Cadiz (SW Iberian Pennninsula). Mar Ecol Prog Ser 390, 79-95.

Fitzwater, S.E., Johnson, K.S., Elrod V.A., Ryan, J.P., Coletti, L.J., Tanner S.J., Gordon R.M., Chavez, F.P., 2003. Iron, nutrient and phytoplankton biomass relationships in upwelled waters of the California coastal system. Cont Shelf Res 23,1523-1544.

Glud, R.N., and Blackburn, N. 2002. The effects of chamber size on benthic oxygen uptake measurements: A simulation study. Ophelia 56: 23-31.

Gordon, L.I., Jennings, J.C., Ross, A.R., Krest, J.M., 1995. A Suggested Protocol for Continuous Flow Automated Analysis of Seawater Nutrients (Phosphate, Nitrate, Nitrite, and Silicic Acid) in the WOCE Hydrographic Program and the Joint Global Ocean Fluxes Study. Oregon State University Technical Report. 93-1 (rev).

Grantham, B.A., Chan, F., Nielsen, K.J., Fox D.S., Barth, J.A., Huyer, A., Lubchenco, J., and Menge, B.A., 2004. Upwelling-driven nearshore hypoxia signals ecosystem and oceanographic changes in the northeast Pacific. Nature 429, 749-754.

Grundle, D.S., Juniper S.K., 2011. Nitrification from the lower euphotic zone to the sub-oxic waters of a highly productive British Columbia fjord. Marine Chemistry 126, 173-181.

Hales, B., Karp-Boss, L., Perlin, A., Wheeler, P.A., 2006. Oxygen production and carbon sequestration in an upwelling coastal margin. Global Biogeochem Cycles 20, GB3001.

Hall, P.O.J., Hulth, S., Hulthe, G., Landen, A., Tengber, A., 1996. Benthic nutrient fluxes on a basin-wide scale in the Skagerrak (NE North Sea). J. Sea Res. 35, 123-137.

Hartnett H.E., Devol A.H. 2003. Role of strong oxygen-deficient zone in the preservation and degradation of organic matter: A carbon budget for the continental margins of the northwest Mexico and Washington State. Geochim Cosmochim Acta 67, 247-264.

Hickey, B.M., Banas, N.S., 2003. Oceanography of the US Pacific Northwest coastal ocean and estuaries with application to coastal ecology. Estuaries 26, 1010-1031.

Horak, R.E.A., Qin W., Shauer, A.J., Armbrust, E.V., Ingalls, A.E., Moffett, J.W., Stahl, D.A., Devol, A.H., 2013. Ammonia oxidation kinetics and temperature sensitivity of a natural marine community dominated by Archaea. ISME 7, 2023-2033.

Huettel, M., Ziebis, W., Forster, S., Luther, G.W. III., 1998. Advective transport affecting metal and nutrient distributions and interfacial fluxes in permeable sediments. Geochim Cosmochim Acta 62, 613-631.

Huyer, A.E., 1983. Coastal upwelling in the California Current system. Progr. Oceanogr. 12: 259-284.

Jahnke, R.A., Emerson, S.R., and Murray, J.W. 1982. A model of oxygen reduction, denitrification, and organic matter mineralization in marine sediments. Limnology and Oceanography 27: 610-623.

Johnson, K.S., Chavez, F.P., Friederich, G.E., 1999. Continental-shelf sediment as a primary source of iron for coastal phytoplankton. Nature 298, 697-700. 
Kachel, N.B., Smith, J.D., 1989. Sediment transport and deposition on the Washington continental shelf, in Coastal Oceanography of Washington and Oregon edited by M.R. Landry and B.M. Hickey, pp. 287-348. Elsevier, Amsterdam.

Keister, J.E., Peterson, W.T., and Pierce, S.D., 2009. Zooplankton distribution and cross-shelf transfer of carbon in an area of complex mesoscale circulation in the northern California Current. Deep Sea Research I 56, 212-231.

Lohan, M.C., Aguilar-Islas, A.M., Bruland, K.W., 2006. Direct determination of iron in acidified (pH 1.7) seawater samples by flow injection analysis with catalytic spectrophotometric detection: Application and intercomparison. Limnology and Oceanography-Methods, 4: 164-171.

Lohan, M.C., Bruland, K.W., 2008. Elevated Fe(II) and dissolved Fe in hypoxic shelf waters off Oregon and Washington: An enhanced source of iron to coastal upwelling regimes. Environ Sci Technol 42, 6462-6468.

McCann-Grosvenor, K., Reimers, C.E., Sanders, R.D., 2014. Dynamics of the benthic boundary layer and seafloor contributions to oxygen depletion on the Oregon inner shelf. Cont Shelf Res 84, 93-106.

Mordy, C.W., Eisner, L.B., Proctor, P., Stabeno, P., Devol, A.H., Shull, D.H., Napp, J.M., Whitledge, T., 2010. Temporary uncoupling of the marine nitrogen cycle: Accumulation of nitrite on the Bering Sea shelf. Mar. Chem. 121, 157-166.

Newell, S.E., Babbin, A.R., Jayakumar, A., Ward, B.B., 2011. Ammonia oxidation rates and nitrification in the Arabian Sea. Global Biogeochem. Cycles 25, GB4016.

Oke, P.R., Allen, J.S., Miller, R.N., and Egbert, G.D., 2002. A modeling study of the threedimensional continental shelf circulation off Oregon. Part II: Dynamical Analysis. Journal of Physical Oceaongraphy 32: 1383-1403.

Paulmier, A., Kreist, I., and Oschlies, A., 2009. Stoichiometries of remineralisation and denitrification in global biogeochemical ocean models. Biogeosciences 6, 923-935.

Perlin, A., Moum, J.N., and Klymak, J.M., 2005. Response of the bottom boundary layer over a sloping shelf to variations in alongshore wind. J. Geophys. Res. 110, C10S09.

Precht, E., Franke, U., Polerecky, L., Huettel, M., 2004. Oxygen dynamics in permeable sediments with wave-driven pore water exchange. Limnol. Oceanogr. 49, 693-705.

Reimers, C.E., Ozkan-Haller, T., Berg, P., Devol, A., McCann-Grosvenor, K., Sanders, R.D., 2012. Benthic oxygen consumption rates determined by eddy correlation during hypoxic conditions on the Oregon continental shelf. J. Geophys. Res. Oceans 117, C02021.

Santoro, A.E., Casciotti, K.L., Francis, C.A., 2010. Activity, abundance and diversity of nitrifying archaea and bacteria in the central California Current. Environ Microbiol 12, 1989-2006.

Severmann, S., McManus, J., Berelson ,W.M., Hammond, D.E., 2010. The continental shelf benthic iron flux and its isotope composition. Geochim Cosmochim Acta 74, 3984-4004.

Siedlecki, S.A., Mahadevan, A., and Archer, D.E. (2012) Mechanism for export of sedimentderived iron in an upwelling regime. Geophys. Res. Lett. doi 10.1029/2011GL050366.

Tengberg, A., Hall, P.O.J., Andersson, U., Linden, B., Styrenius, O., Boland, G.,de Bovee, F., Carlsson, B., Ceradini, S., Devol, A., Duineveld, G., Friemann, J.U., Glud, R.N., Khripounoff, A., Leather, J., Linke, P., Lund-Hansen, L., Rowe, G., Santschi, P., de Wilde, P., Witte, U., 2005. Intercalibration of benthic flux chambers II. Hydrodynamic characterization and flux comparisons of 14 different designs. Mar. Chem. 94, 147-173. 
Tynan, C.T., Ainley, D.G., Barth, J.A., Cowles, T.J., Pierce, S.D., and Spear, L.B., 2005. Cetacean distributions relative to ocean processes in the northern California Current System. Deep Sea Research II 52, 145-167.

Whitney, F.A., Freeland, H.J., and Robert, M., 2007. Persistently declining oxygen levels in the interior waters of the eastern subarctic Pacific. Progr. Oceanogr 75, 179-199. 
Figure captions

Figure 1. A map of the study region indicating station locations and near bottom water concentrations (inner circles for June and outer circles for August) of A) oxygen and B) ammonium.

Figure 2. An example of a chamber incubation experiment from June 2009 event \#86 at station SH80.

Figure 3. A compilation of A) oxygen, B) nitrate, C) ammonium and D) iron benthic fluxes from the continental shelves of Washington (Devol and Christensen, 1993; Hartnett and Devol, 2003), Oregon (Severmann et al., 2010; Berelson et al., 2013; this study, eddy flux: Reimers et al., 2012; McCann-Grosvenor et al., 2014) and California (Berelson et al., 1996; Elrod et al., 2004; Severmann et al., 2010; Berelson et al., 2013).

Figure 4. Given measured $\mathrm{O}_{2}$ and $\mathrm{NH}_{4}{ }^{+}$concentrations and average benthic fluxes, we varied water column respiration rates and calculated the change in A) water residence time, B) ammonia oxidation rates, C) percent ammonium originating from benthic fluxes for August 2009 stations NH50 (blue), NH80 (purple) and SH80 (red) D) percent oxygen consumed by benthic fluxes (lines) and by ammonia oxidation (symbols). The vertical dotted line in panel B indicates the maximum ammonia oxidation rate measured by Santoro et al (2010) off California. The grey box indicates the space where water column respiration, residence time, and ammonia oxidation are all within reasonable parameters. Points are calculated using a $0.6 \mathrm{mmol} / \mathrm{m}^{2} \mathrm{~d}$ benthic ammonium flux and a $-8.0 \mathrm{mmol} \mathrm{m} \mathrm{d}^{-1}$ oxygen flux and other parameters measured at each station (Table 5). 

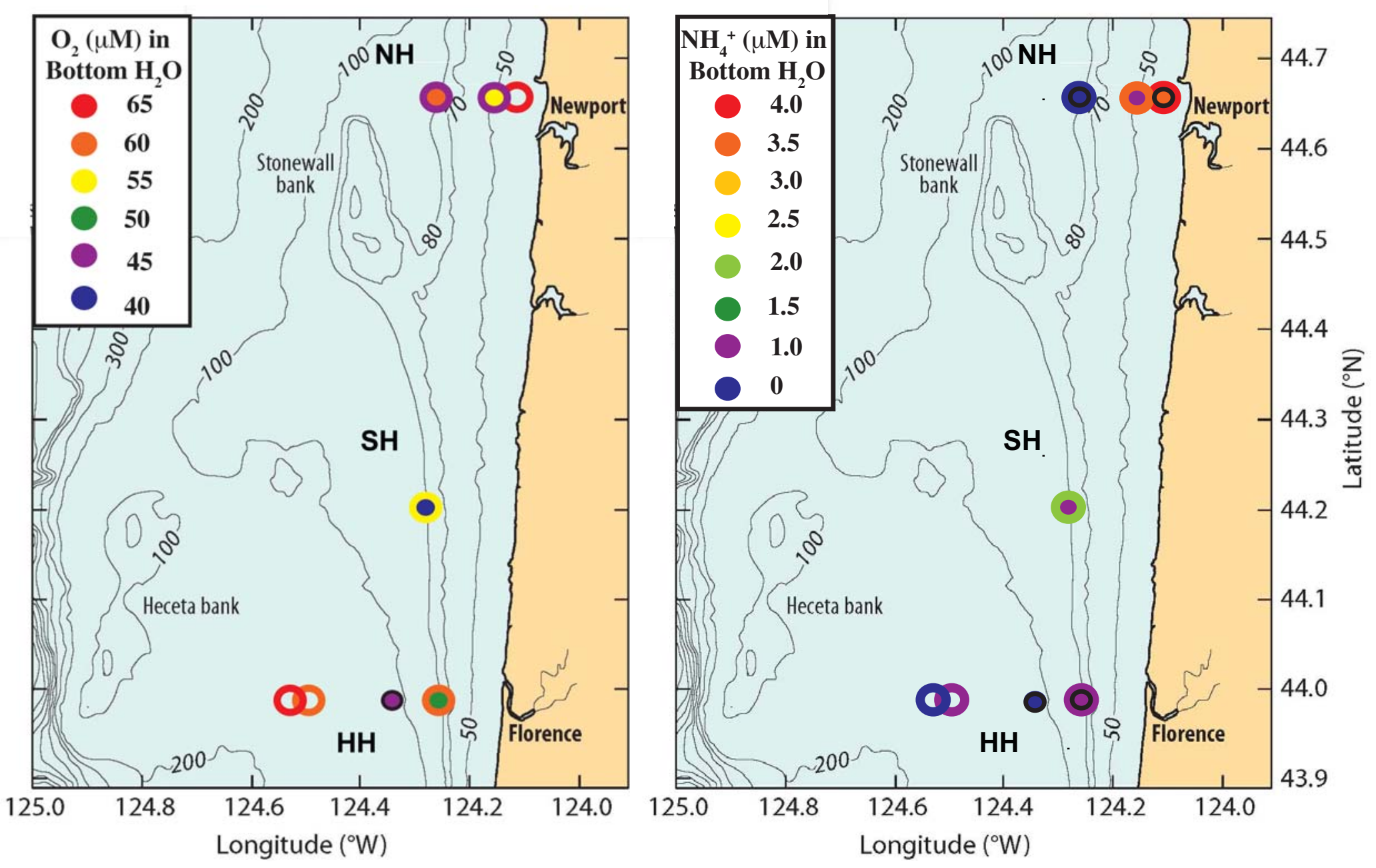

Fig.1 

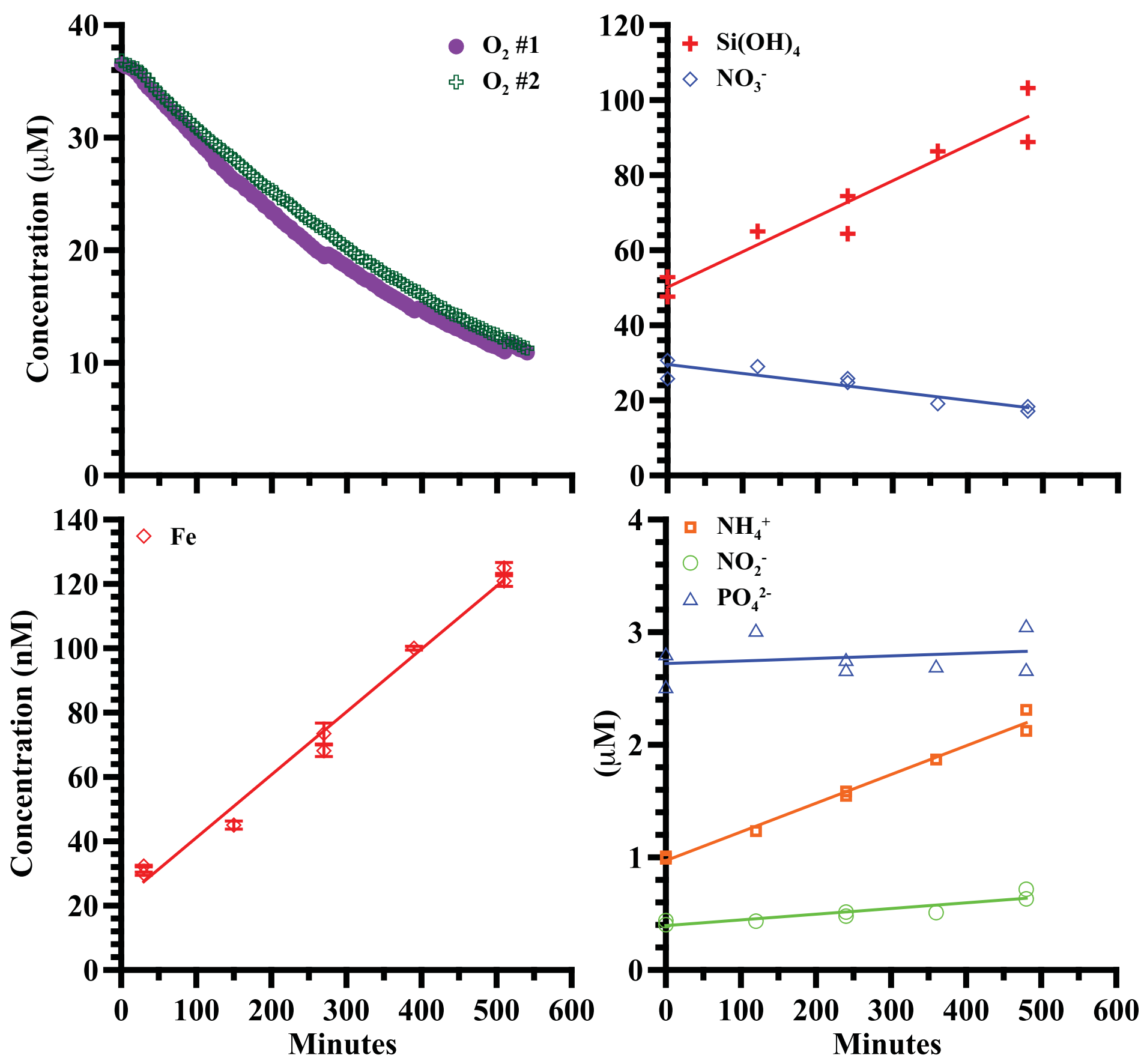

Fig. 2 

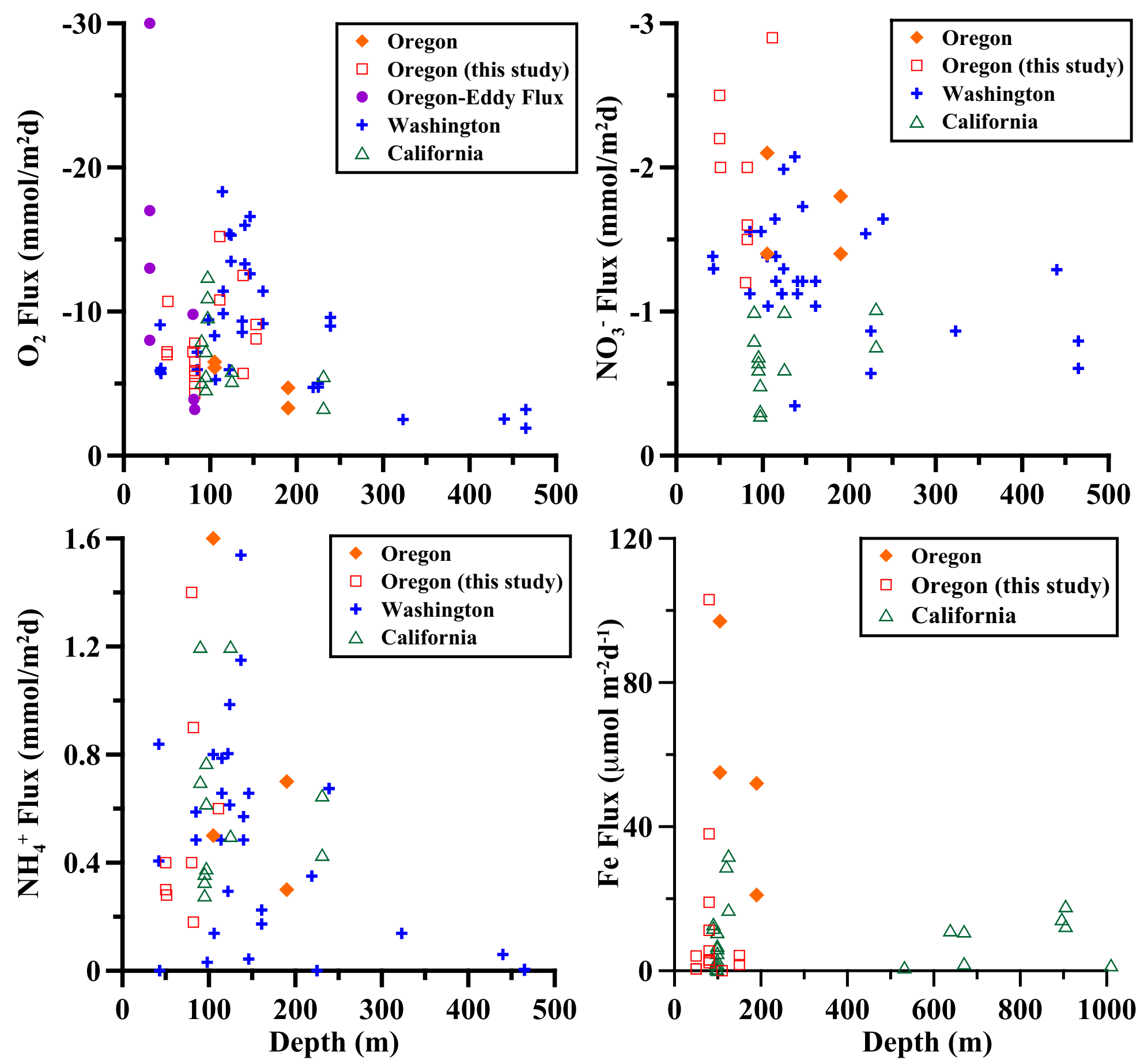

Fig. 3 

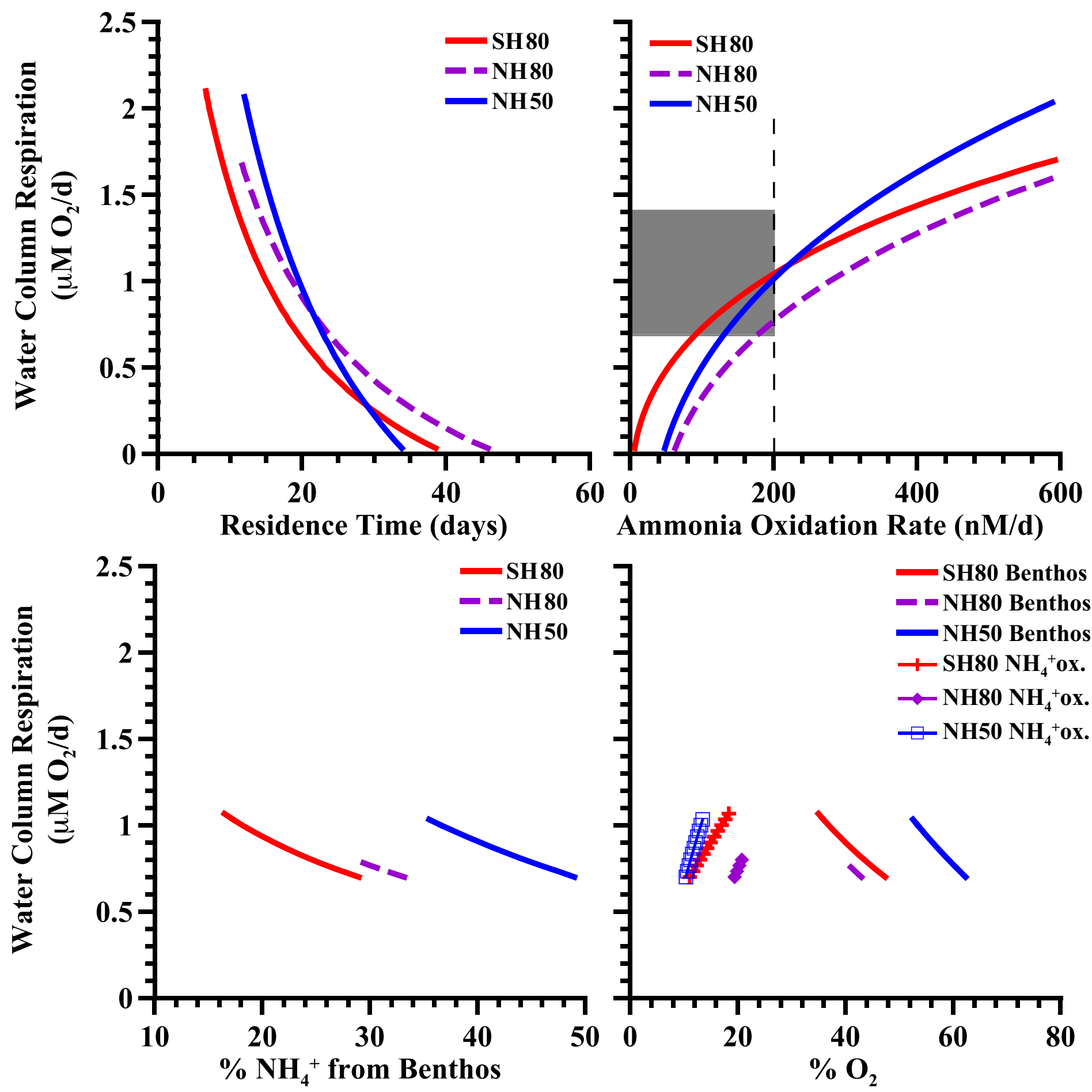

Fig. 4 


\section{Tables}

Table 1. Station bottom water conditions. Samples collected from Niskin bottles on a Fe CTD/rosette package, tripped $4 \mathrm{~m}$ above the bottom. Temperature in ${ }^{\circ} \mathrm{C}$. Concentrations in $\mu \mathrm{M}$, except for $\mathrm{Fe}$, which is nM. n.d. indicates values not determined. Estimated uncertainties of measurements is: $\mathrm{T}, \pm 0.01^{\circ} \mathrm{C} ; \mathrm{S}, \pm 0.01$; sigma, $\pm 0.01 ; \mathrm{O}_{2}, \pm 1 \mu \mathrm{M} ; \mathrm{NO}_{3}{ }^{-}, \pm 0.1 \mu \mathrm{M} ; \Sigma \mathrm{PO}_{4}, \pm$ $0.03 \mu \mathrm{M} ; \Sigma \mathrm{SiO}_{4}, \pm 2 \mu \mathrm{M} ; \mathrm{Fe} \pm 0.5 \mathrm{nM}$.

\begin{tabular}{lllllllllll}
\hline Cruise & Station & $\mathrm{T}$ & $\mathrm{S}$ & $\sigma$ & {$\left[\mathrm{O}_{2}\right]$} & {$\left[\mathrm{NO}_{3}{ }^{-}\right]$} & {$\left[\mathrm{NH}_{4}{ }^{+}\right]$} & {$\left[\Sigma \mathrm{PO}_{4}\right]$} & {$\left[\Sigma \mathrm{SiO}_{4}\right]$} & {$[\mathrm{Fe}]$} \\
\hline June & $\mathrm{NH} 30$ & 9.02 & 33.44 & 25.89 & 167 & 17.4 & 3.5 & 1.97 & 11 & n.d. \\
June & $\mathrm{NH} 50$ & 7.50 & 33.81 & 26.41 & 56 & 33.6 & 1.0 & 2.95 & 41 & n.d. \\
June & $\mathrm{SH} 80$ & 7.36 & 33.86 & 26.47 & 41 & 32.7 & 0.9 & 3.15 & 68 & n.d. \\
June & $\mathrm{HH} 80$ & 7.41 & 33.84 & 26.45 & 53 & 33.7 & 1.2 & 3.05 & 61 & 22 \\
June & $\mathrm{HH} 110$ & 7.10 & 33.96 & 26.59 & 47 & 36.0 & 0.2 & 2.93 & 63 & 26 \\
Aug & $\mathrm{NH} 30$ & 8.90 & 33.74 & 26.15 & 63 & 27.9 & 4.0 & 3.01 & 45 & n.d. \\
Aug & $\mathrm{NH} 50$ & 7.83 & 33.79 & 26.35 & 43 & 30.2 & 2.6 & 3.13 & 63 & n.d. \\
Aug & $\mathrm{NH} 80$ & 7.60 & 33.84 & 26.42 & 45 & 34.8 & 0.0 & 3.01 & 63 & n.d. \\
Aug & $\mathrm{SH} 80$ & 7.77 & 33.90 & 26.44 & 55 & 32.0 & 2.1 & 3.00 & 64 & n.d. \\
Aug & $\mathrm{HH} 80$ & 7.41 & 33.84 & 26.45 & 60 & 34.2 & 0.9 & 3.17 & 70 & n.d. \\
Aug & $\mathrm{HH} 140$ & 7.80 & 33.90 & 26.43 & 62 & 35.0 & 1.0 & 2.93 & 58 & n.d. \\
Aug & $\mathrm{HH} 150$ & 7.85 & 33.96 & 26.48 & 66 & 34.2 & 0.1 & 2.72 & 49 & n.d. \\
\hline
\end{tabular}


Table 2. Lander deployment stations. Cruise Event \# refers to the deployment in the order of operations during each cruise. n.d. indicates values not determined.

\begin{tabular}{|c|c|c|c|c|c|c|c|c|}
\hline $\begin{array}{l}\text { Deplo- } \\
\text { yment }\end{array}$ & Cruise & $\begin{array}{c}\text { Cruise } \\
\text { Event \# }\end{array}$ & $\begin{array}{l}\text { Date } \\
\mathrm{m} / \mathrm{dd}\end{array}$ & Lat $\mathrm{N}$ & Long W & $\begin{array}{l}\text { Station } \\
\text { ID }\end{array}$ & $\begin{array}{l}\text { Depth } \\
\text { (m) }\end{array}$ & Sediment \\
\hline $\mathrm{J} 1$ & June & 38 & $6 / 09$ & $44^{\circ} 39.2$ & $124^{\circ} 08.8$ & NH50 & 51 & Sand \\
\hline $\mathrm{J} 3$ & June & 57 & $6 / 11$ & $43^{\circ} 56.3$ & $124^{\circ} 14.7$ & HH80 & 80 & $\begin{array}{l}\text { Muddy } \\
\text { sand }\end{array}$ \\
\hline J4 & June & 75 & $6 / 12$ & $43^{\circ} 55.8$ & $124^{\circ} 19.2$ & HH110 & 111 & Silty mud \\
\hline J5 & June & 86 & $6 / 13$ & $44^{\circ} 14.0$ & $124^{\circ} 18.9$ & SH80 & 82 & Sand \\
\hline A1 & August & 3 & $8 / 15$ & $43^{\circ} 55.9$ & $124^{\circ} 30.4$ & HH140 & 139 & n.d. \\
\hline $\mathrm{A} 2$ & August & 14 & $8 / 16$ & $43^{\circ} 55.9$ & $124^{\circ} 33.1$ & HH150 & 153 & n.d. \\
\hline A3 & August & 27 & $8 / 17$ & $43^{\circ} 56.7$ & $124^{\circ} 14.8$ & HH80 & 79 & $\begin{array}{l}\text { Muddy } \\
\text { sand }\end{array}$ \\
\hline A6 & August & 54 & $8 / 20$ & $44^{\circ} 39.4$ & $124^{\circ} 18.0$ & NH80 & 82 & Sand \\
\hline A7 & August & 64 & $8 / 21$ & $44^{\circ} 14.7$ & $124^{\circ} 18.9$ & SH80 & 81 & Sand \\
\hline A8 & August & 74 & $8 / 22$ & $44^{\circ} 39.3$ & $124^{\circ} 08.9$ & NH50 & 50 & Sand \\
\hline
\end{tabular}

Deployments $\mathrm{J} 2$ at NH30 and A5 at NH30 returned no usable benthic flux data. 
Table 3. Benthic fluxes of nutrients and iron. All fluxes in $\mathrm{mmol} \mathrm{m}^{-2} \mathrm{~d}^{-1}$ except Fe, which is in $\mu \mathrm{mol} \mathrm{m} \mathrm{m}^{-2}$. n.d. is not determined. --- indicates fluxes with two few data points or inconsistent trends.

\begin{tabular}{|c|c|c|c|c|c|c|}
\hline Station & $\mathrm{O}_{2} \mathrm{~A} / \mathrm{B}$ & $\mathrm{NO}_{3}{ }^{-}$ & $\mathrm{NH}_{4}^{+}$ & $\mathrm{NO}_{2}^{-}$ & $\mathrm{Si}$ & $\mathrm{Fe} \mathrm{A} / \mathrm{B}$ \\
\hline \multicolumn{7}{|c|}{ June } \\
\hline NH50 & $\begin{array}{l}\text { n.d./ } \\
-10.7 \pm 0.8\end{array}$ & $-2.05 \pm 0.03$ & $0.28 \pm 0.06$ & $0.2 \pm 0.02$ & $2.8 \pm 0.4$ & $\begin{array}{l}0.46 \pm 0.01 / \\
\text { n.d. }\end{array}$ \\
\hline SH80 & $\begin{array}{l}-5.0 \pm 0.04 / \\
-4.3 \pm 0.04\end{array}$ & $-1.6 \pm 0.6$ & $0.18 \pm 0.01$ & $0.021 \pm 0.005$ & $7 \pm 1$ & $\begin{array}{l}11.2 \pm 0.4 / \\
\text { n.d. }\end{array}$ \\
\hline HH80 & $\begin{array}{l}-7.2 \pm 0.3 / \\
\text { n.d. }\end{array}$ & $-1.2 \pm 0.2$ & $0.4 \pm 0.1$ & $0.10 \pm 0.01$ & $1.2 \pm 0.2$ & $\begin{array}{l}2.28 \pm 0.03 / \\
3 *\end{array}$ \\
\hline HH110 & $\begin{array}{l}-10.9 \pm 0.08 \\
/-15.2 \pm 0.5\end{array}$ & $-2.9 \pm 0.5$ & $0.6 \pm 0.2$ & $0.11 \pm 0.06$ & $7 \pm 1$ & $\begin{array}{l}-0.02 \\
\pm 0.001\end{array}$ \\
\hline \multicolumn{7}{|c|}{ August } \\
\hline NH50A & $-7.0 \pm 0.1$ & $-2.2 \pm 0.2$ & $0.30 \pm 0.08$ & --- & $7.8 \pm 0.9$ & $4.1 \pm 0.8$ \\
\hline NH50B & $-7.2 \pm 0.2$ & $-2.5 \pm 0.2$ & $0.41 \pm 0.05$ & --- & $7.2 \pm 0.5$ & $0.52 \pm 0.01$ \\
\hline NH80 & $\begin{array}{l}-5.5 \pm 0.06 / \\
-5.8 \pm 0.04\end{array}$ & $-2.0 \pm 0.1$ & $0.9 \pm 0.3$ & $0.06 \pm 0.05$ & $8.7 \pm 0.4$ & $\begin{array}{l}3 * / 5.54 \\
\pm 0.09\end{array}$ \\
\hline SH80 & $\begin{array}{l}-7.8 \pm 0.09 / \\
-6.4 \pm 0.2\end{array}$ & --- & --- & --- & --- & $38 \pm 3$ \\
\hline HH80 & $\begin{array}{l}\text { n.d./ } \\
-6.7 \pm 0.1\end{array}$ & $-1.5 \pm 0.2$ & $1.4 \pm 0.2$ & $0.07 \pm 0.01$ & $11 \pm 1$ & $19 \pm 3 / 71 *$ \\
\hline HH140 & $\begin{array}{l}-5.8 \pm 0.1 / \\
-12.5 \pm 0.2\end{array}$ & --- & --- & --- & --- & --- \\
\hline HH150 & $\begin{array}{l}-8.1 \pm 0.2 / \\
-9.1 \pm 0.05\end{array}$ & --- & --- & --- & --- & $\begin{array}{l}1.74 \pm 0.01 / \\
4.2 \pm 0.2\end{array}$ \\
\hline
\end{tabular}

- based on 2 time-points

Table 4. Calculated integrated diagenetic reactions where Ac represents aerobic $\mathrm{C}$ degradation and $\mathrm{Nc}$ represents organic carbon degraded by denitrification, and $\mathrm{TC}_{\mathrm{ox}}$ is the total carbon oxidized and $\mathrm{NH}_{4}$,prod is the ammonia produced during organic matter degradation. The columns represent the calculations using linear fit $\mathrm{O}_{2}$ fluxes. Fluxes are in mmol m $\mathrm{m}^{-2}$. $\mathrm{N}_{2}$ is reported as twice the $\mathrm{N}_{2}$ flux from equation $8\left(\mathrm{mmol} \mathrm{N} \mathrm{m}^{-2} \mathrm{~d}^{-1}\right)$.

\begin{tabular}{llrrrrrrl}
\hline & Station & $\mathrm{Ac}$ & $\mathrm{Nc}$ & $\mathrm{TC}_{\mathrm{ox}}$ & $\mathrm{Ac} / \mathrm{Nc}$ & $\mathrm{N}_{2}$ & $\mathrm{NH}_{4, \text { prod. }}$ & $\mathrm{NH}_{4, \mathrm{ox}}$ \\
\hline & & \multicolumn{7}{c}{ June } \\
J1 & $\mathrm{NH} 50$ & 7.1 & 3.8 & 11.0 & 1.9 & 3.4 & 1.7 & 1.4 \\
J5 & SH80 & 3.0 & 2.5 & 5.5 & 1.2 & 2.3 & 0.8 & 0.6 \\
J3 & HH80 & 5.2 & 2.1 & 7.3 & 2.4 & 1.9 & 1.1 & 0.7 \\
J4 & HH110 & 9.0 & 4.9 & 14.0 & 1.8 & 4.4 & 2.1 & 1.5 \\
& & \multicolumn{7}{c}{ August } \\
A8 & NH50 & 4.7 & 3.6 & 8.3 & 1.3 & 3.3 & 1.3 & 1.0 \\
A6 & NH80 & 4.7 & 2.5 & 7.2 & 1.9 & 2.2 & 1.1 & 0.2 \\
A3 & HH80 & 6.1 & 1.6 & 7.7 & 3.8 & 1.5 & 1.2 & 0 \\
\hline
\end{tabular}


Table 5. Measured values for BBL thickness, bottom water ammonia concentrations, difference between offshore and shelf oxygen concentrations, and calculated values for residence time, ammonia oxidation rates and the $\%$ ammonia production and oxygen consumption from the benthos as determined by a simple model.

\begin{tabular}{lccccccc}
\hline & $\begin{array}{c}\mathrm{BBL} \\
(\mathrm{m})\end{array}$ & $\begin{array}{c}{\left[\mathrm{NH}_{4}{ }^{+}\right]} \\
(\mu \mathrm{M})\end{array}$ & $\begin{array}{c}\mathrm{O}_{2} \text { diff. } \\
(\mu \mathrm{M})\end{array}$ & $\tau$ (days) & $\begin{array}{c}\text { benthic } \\
\mathrm{O}_{2}\end{array}$ & $\begin{array}{c}\text { benthic } \\
\mathrm{NH}_{4}{ }^{+}\end{array}$ & $\begin{array}{c}\mathrm{NH}_{4}^{+} \text {ox. } \\
(\mathrm{nM} / \mathrm{d})\end{array}$ \\
\hline NH50 & 5 & 2.6 & 44 & $19-22$ & $52-62 \%$ & $35-48 \%$ & $133-205$ \\
NH80 & 10 & 0 & 58 & $21-23$ & $39-43 \%$ & $28-33 \%$ & $180-209$ \\
SH80 & 10 & 2.1 & 32 & $14-19$ & $35-47 \%$ & $16-29 \%$ & $93-209$ \\
\hline
\end{tabular}

